\title{
Introduction: Reinscribing Nuruddin Farah in African literature
}

\section{F. Fiona Moolla}

"Literary provocations: Nuruddin Farah five decades on" was a project conceived by Tydskrif vir Letterkunde as a festschrift honoring the career of one of the most well-known, but also most underrepresented, authors in African literature. Farah has been a prolific author, with thirteen novels to date, translated into many world languages, and whose creativity in his seventies proceeds apace with another novel and a non-fiction work in progress. He has won prestigious literary awards, most notably the 1998 Neustadt Prize, and his novels in translation have won major Italian and French awards. Despite these international indices of recognition, Farah has not enjoyed the prominence in African literature circles of figures like Chinua Achebe, Wole Soyinka or Ngũgĩ wa Thiong’o. On the international literary scene, Farah has a very strong presence in the American media with reviews of novels and publication of opinion pieces on Somali socio-political questions in major newspapers, and interviews at major literary events and on popular television chat shows. It is curious therefore that Farah has not been recognized through a special issue of an American literary journal where his reputation is probably strongest except for a special issue of World Literature Today (vol. 72, no. 4, 1998) on the occasion of Farah's receipt of the Neustadt Prize.

The commissioning of a theme issue on the work of Farah in a South African literary journal therefore is noteworthy both in African continental and world literature contexts. Commemorating Farah's career in Tydskrif vir Letterkunde may be seen as an attempt at a reconsideration of Farah's position in African literature, and an acknowledgement of the possible reconfiguration of Farah as a South African writer, in addition to his position as a "Somali" diasporic writer. Hein Willlemse, former editor-in-chief of Tydskrif vir Letterkunde, explains the journal's interest in Farah mainly through cognizance of the relative disparities between Farah, on the one hand, and Achebe, Soyinka and Ngũgĩ, the canonized triumvirate of African authors, on the other. Willemse identifies three main reasons for Farah's relatively marginal position: The first relates to the major focus in much of Farah's fiction on questions of gender that up until the late twentieth century, mainly through the literature and activism of African women writers, did not receive much attention. Willemse suggests that:

Farah was published [...] towards the end of the first wave of Nigerian writing, and the first autobiographical writings of the post-independence generation of African writers. African literature as a discipline was still being established and much of the literary attention had been on Achebe, Soyinka, and the wave of post-independence writers, the apartheid struggle and people like Nkrumah, Kenyatta, Mandela and the like. The little-known Farah studied in India, wrote a slim novella on a woman's struggle for liberation against male dominance. This in itself meant that Farah initially found himself outside the mainstream of this newly developing discipline which settled itself in London, and the east coast of the USA. The theme of his first work was not a major consideration for the first generation of writers or critics. Most of the critics were male, their attention was focused on independence realpolitik (postcoloniality as a distinct theoretical discipline did not exist), and defining African particularity (Leopold Senghor etc.) rather than issues of gender. (Willemse and Moolla)

The second reason Willemse identifies for the relative lack of attention to Farah lies in the particularities of the exceptionality of Somalia's history and its history of colonization, in particular, where "its primary nexus is not the major colonial powers, the British or the French, but rather the Arabs and the Italians". He suggests further that Farah falls beneath the radar for reasons linked with the genealogies of the study of African literature where "[...] the growth of African literature and critical attention was spawned not by publishers and critics in African locales but rather by diasporan metropolitan African intellectuals, and fellow travelers". Willemse refers to the African intellectual communities that gathered in London, Paris, New York, Chicago and Los Angeles, where

F. Fiona Moolla is associate professor in the English Department, University of the Western Cape, Bellville, South Africa. She is the author of Reading Nuruddin Farah: The Individual, the Novel \& the Idea of Home (James Currey, 2014).

Email: fmoolla@uwc.ac.za

iD https://orcid.org/0000-0001-7809-2222

D0l: https://doi.org/10.17159/2309-9070/tvl.v.57il.7981

TYDSKRIF VIR LETTERKUNDE • 57(1) 2020

ISSN: 0041-476X E-SSN: 2309-9070

(0) 2020. Tydskrif vir Letterkunde. Published under a Creative Commons Attribution License. 
"the first impulses of African literature as a discipline" grew. He adds that it was in these metropolitan centers that "the key areas of African literary focus were established: West Africa (mainly Nigerian and Ghana, with the French looking at Leopold Senghor and Senegal), East African (mainly Kenyan literature) and Southern Africa (mainly anti-apartheid Black English writing)". Willemse argues that "[t]he countries adjacent to these three main areas were neglected, just as the Mahgreb and Arab literature and Lusophone writing got little attention" (Willemse and Moolla). Against this background of regional "canonization", the possibility that a writer from the Horn of Africa should emerge as a central figure in African literature, Willemse feels, would be highly unlikely.

A third factor mentioned by Willemse relates to the politics of publication. He suggests that if one considers the nationalities and relationships of editors of twentieth-century publishing houses and African literary journals, few of them would have had significant connection with Somalia and the Horn of Africa, more generally. Bearing in mind that literary canonization "has a lot to do with publishing and educational power", Willemse concludes that the relative neglect of Farah is hardly surprising in the "quotidian processes of canonization" (Willemse and Moolla).

Thus, the theme issue was commissioned as a response to this scenario, but also in an attempt to redress a perceived imbalance in the literary "knowledge economy" where "the best and most consistent training and publication of African literature" occurs in the global north, with the input of major African critics, writers and resources. In this context, the "concentrated effort of developing African literature on the African continent has been somewhat neglected" (Willemse and Moolla). Tydskrif vir Letterkunde as a South African journal with a commitment to African literature more broadly, would appear to be attempting a reconfiguration from the global south of the map of African literature drawn mainly in the global north. A related question, and one that will be picked up later in this introduction, is the question of the position of Farah in the South African literary landscape specifically.

The theme issue was also conceived as an incitement to look at Farah in daring and thought-provoking new ways. To a certain extent, transformed ways of thinking about Farah are a challenge presented by the author himself who, despite continuities, has struck out in alternative directions in his recent writing, and work in progress. The theme issue was conceptualized as a calling forth of voices that would interrogate the work of the mature, fully established Farah in the broader context of Somali, African and world literature, and in the context of new literary networks, more specifically. The contributions in this theme issue from emerging and established "globally located" Farah scholars signpost important new directions in a rapidly transforming twenty-first century literary landscape.

Many more questions remain: Unsettling familiar geographic frames of reference of a self-contained Africa with impermeable internal borders, shores as frontiers, and the Sahara as territorial divide, why should Farah not be considered part of a nomad network including the Libyan, Ibrahim al-Koni, the Egyptian, Sabri Moussa, or even the Saudi, Abd al-Rahman Munif? The constitutive creative matrix of a nomadic desert environment, refracted by orality, Islam and Arab culture, as well as common social concerns regarding the relationship between the truths of story and the political mononarratives of postcolonial tyrannies joins these writers into an alliance forged by similar alembics of personal formation, literary styles and social considerations. In this regard, Ali Jimale Ahmed reminds us of the "Arab factor" in Farah's novels, citing Farah's observation that in many ways his writing is closer to a North African aesthetic than a West African one, owing to the influences of Islam and the Arab legacy, captured in the Thousand and One Nights, which he read as a child (Ahmed 26). Another conceptualization of Farah in an Arab context is represented by Tayseer Abu Odeh in "The Pleasures and Pitfalls of Exile and Counterpoint in Farah's Maps" in a recent issue of Arab Studies Quarterly. This essay frames Farah's narrative of exile with that of Edward Said, and through Edward Said, with exile as it reverberates in the work of Palestinian poet, Mahmoud Darwish. Scholarship of the novels of Farah's early to mid-career underscores the keen and thoroughgoing focus on complex representations of female subjectivity. Given the focus on women in his work and his politics, why has Farah not been drawn into the center of current debates in African feminism and/or womanism, drawing his work into a sustained conversation with that of Flora Nwapa, Buchi Emecheta, Ama Ata Aidoo, Mariama Bâ, and Bessie Head - a writer whose preoccupations and modes of writing could not be more similar to those of Farah? Farah's novels and non-fiction essays and books also consciously privilege an understanding of cosmopolitanism that ought to draw him into the diasporic "Afropolitan" circle that includes Taiye Selassie, Chimamanda Ngozi Adichie, Teju Cole, and others. Again, what imaginative constraints, apart from the difference in age, close off the conceptualization of such new literary networks? 
I considered I considered relinquishing the dutiful (and predictable) preamble to any piece on Farahbut found that I could not. So here it is: Somali writer, Nuruddin Farah Hassan, was born in 1945 in the Italian administered town of Baidoa in the South of Somalia, after which his family moved to Kallafo in the Ethiopianoccupied Ogaden region mainly to further Farah's education, and that of his siblings. Farah then completed his secondary studies in Mogadishu, the capital of the Italian colonial south. (The greater Somalia has the unique distinction of having had four of its territories colonized—or occupied—by Britain, Italy, France, and Ethiopia, and the fifth territory ceded to Kenya by Britain. The lost territories are symbolically represented by each of the points on the five-pointed star of its flag.) Farah then proceeded to do an undergraduate Arts degree at Panjab University, Chandigarh, India, in preference to study in the United States for which he had received a scholarship-biographical information he discusses in some detail in the interview conducted for this issue. He has been outside of Somalia since 1974 and in exile since 1976 because of the threat of incarceration from the military dictatorship of Muhammed Siyad Barre after the publication of his second novel, A Naked Needle, perceived to undermine the regime for its focus on bourgeois rather than socialist-revolutionary issues. Since 1991, Farah has been a "refugee" of the catastrophic civil war that erupted when Barre fled Somalia. In the twenty-first century, Farah may be considered part of the Somali diaspora displaced from Somalia as a consequence of internal political disputes, inflamed and exacerbated by external political interests. In this extended period of his exile, Somalia has existed as the "country" of his "imagination", being written into existence from cities in Europe, North America and Africa. (Farah maintains, as iterated in the interview for this theme issue, that, resident in African cities, he does not regard himself as exiled from Somalia.) Farah traces his origins as a writer to the influence of his mother's oral poetry, and the varied books he read in English and Arabic as a child. Farah read Egyptian writers and poets, and also read Fyodor Dostoevsky and Victor Hugo in Arabic translation. Other literary influences include the works of Virginia Woolf, James Joyce, Ernest Hemingway, William Faulkner, and Samuel Beckett, among others, revealing a predilection, as the list shows, mainly for modernist writers. Unlike most other African writers whose oeuvres are varied, including short fiction, drama, poetry, children's fiction, life writing, and essays, Farah, after an early foray into theater has predominantly been a novelist with only a few forays into the short story, a number of essays, yet to be anthologized, and a non-fiction book on Somali refugees. Since the outset of his career, Farah's language of publication has been English, with an early novel in Somali, and a partially written early novel in Italian. (Farah is distinguished for being both the first Somali novelist, with the publication of From a Crooked Rib, and the author of the first novel in Somali that was serialized in the late 1960s in the leading Mogadishu newspaper.) A renowned polyglot, English is Farah's fourth language after Somali, Arabic and Amharic, and then later also Italian.

The obligatory preamble, routine though it may be, actually alerts one to a number of possible departures from conventional approaches to Farah. Notably, focusing more thoughtfully on Farah's extended absence from Somalia, one recognizes that the familiar category of "exile" may need to be alternately reconfigured. With the greater Somalia divided into the relatively stable Djibouti and Somaliland, and with ongoing tensions and violence in southern Somalia, Somali nationhood is as complex a question as ever it was. Farah's sojourns in various cities in various countries on various continents have never been so extended as to give him a "hyphenated", diasporic identity. However, since 1999, Farah's time has been divided between Cape Town, where he has a family home, and the United States, where he has had teaching commitments. Farah's most recent published novels, Hiding in Plain Sight (2014), North of Dawn (2018), and the proposed new novel, are/will be set in Nairobi, Oslo, and Johannesburg respectively, and the protagonists of these novels are no longer Somali nationals. At what point does one question the knee-jerk classification of Farah as a "Somali writer", or what literary "capital" does its continued use give the author? Since he has been resident in South Africa for more than twenty years, the critical establishment may need to begin thinking of Farah as a Somali-South African writer, a South African Somali writer, or even as a South African writer. In this respect, the South African state Department of Arts and Culture would appear to be ahead of the literary establishment, honoring Farah with a South African Lifetime Achievement Literary Award in 2014, where awards in all the other categories were given to South African authors in the narrow sense.

In this scenario, the transnationalism of South African literature also needs to be rethought and conceptualized more widely, paying attention to the multifarious and multi-directional lines of literary exchange and networked constructions of literary fields. In "Reimagining South African Literature?" a review article of three major surveys of South African literature, Duncan Brown highlights the complexities of the concept of South African literature both pre-and post-1994, where the idea of a unitary nation and the secure boundaries of that nation are 
provocatively questioned in the literary scholarship he engages. In the context of issues of transnationalism being addressed here, only this dimension of Brown's overviews of South African literature will be foregrounded. Brown draws attention to Michael Chapman's introduction to SA Lit Beyond 2000 where Chapman suggests that recent monographs like "Shane Graham's South African Literature after the Truth Commission [2009] and Monica Popescu's South African Literature beyond the Cold War [2010], [...] undertake a 'mapping, or remapping, of the literary terrain', both of which emphasise that South African literary studies is increasingly taking a "transnational turn" (Chapman qtd in Brown 1121). Brown observes further that: "Chapman argues that, post-2000, 'the current priority might be how to connect in a society which at the same time is alert to [a] "transnational" perspective" (1121) in many works of South African fiction. But despite significant scholarly attention being given to the increasing transnationalism of South African literature post-1994, the potential transnationalism of South African literature from the other direction has escaped attention. There is a growing body of "migrant" literature, for example, Yewande Omotoso's Bom Boy, Novuyo Rosa Tshuma's Shadows and Farah's forthcoming novel about Somali migrants in Johannesburg that may signal the development of new literatures that might also form part of South African literature. The present introduction remains sensitive, however, to Brown's call for an attention to South African literature that is less "monumental and institutionally proclaimed", focused instead on "what it means to be human, humane, civil, compassionate" (1123). The present identification of general trends hopes finally to open up to more nuanced reflections of specific works in an extended South African literature. Reflecting, as his novels do, the inescapable transnationalism of the Somali experience, perhaps Farah is the writer whose own life and work highlight the increasing inapplicability of the conventional national model of literary classification. These are questions that the articles in this theme issue address from different points of view.

The question of language alluded to in the preamble is also opened up in new ways by current directions in scholarship. Farah's use of English as language of publication has always been somewhat contentious. Writing with the focused political intention of transforming hearts and minds in his natal country, critics both Somali and international, have observed the contradiction of writing in a foreign language for a largely non-literate, Somali-speaking society. In response, Farah has noted that Somali did not have a formalized script and orthography when he began to write, and that to write in an indigenous language would have trapped him in very local politics, simultaneously excluding him from broader international exchanges of ideas. However, pushing through linguistic borders, some of the essays and articles in this theme issue point at the ways that Farah's literary legacy may extend across languages. In particular, an interesting border-crossing between English and Italian is presently being undertaken and explored. Farah's closeness to Italian literature and culture is evident in all of his novels, going back to the first. This is the consequence of the Italian colonial foray into the Horn of Africa, which left its mark in local language, cuisine, and culture. The Italo-Somali work of authors like Ubah Cristina Ali Farah, Shirin Ramzanali Fazel and Igiaba Scego is being hailed as a postcolonial minority literature, in the sense of the use of the term "minor" by Gilles Deleuze and Felix Guattari. This literature is regarded as foregrounding a repressed Italian colonial history, and a racist, discriminatory anti-immigrant present. Farah's closeness to Italian society, evident in Italian literary and cultural allusions in most of his novels, the fact that most of his works have been translated into Italian, and his position as literary forerunner for a younger generation of Italo-Somali diasporic writers, have located Farah as pivotal in the world of postcolonial Italian letters even though he is an Anglophone writer. The comparative interest in the work of Farah with that of a new generation of diasporic Somali writers extends, however, beyond Italian literature to the British-Somali diasporic writing of Nadifa Mohamed and Diriye Osman, among others.

The publication of the Nuruddin Farah theme issue of Tydskrif vir Letterkunde has been timed to coincide with the fiftieth anniversary of the publication of From a Crooked Rib, the first Somali novel, published in the Heinemann African Writers Series in 1970. This novel, which drew on parts of drafts of an earlier novel, was written by Farah in a month and a half at the Panjab University in Chandigarh. Farah at this point in his life was spurred to write by his disillusionment with his studies and getting a degree, and his especial umbrage at Heinemann Nigeria's rejection of an earlier manuscript he had sent them. From a Crooked Rib is a story about Ebla, a young nomadic girl, who escapes her encampment and arranged marriage for the city of Mogadishu and its complex and contradictory freedoms, where she contracts her own multiple marriages. In his statement of nomination to the 1998 Neustadt jury, Ngũgĩ identifies Farah as "probably the leading writer in Africa in feminist consciousness" (716). Ngũgĩ goes on to say: "This is not a consciousness which he has acquired in the course of his writing; it is at the core of his writing from his very first work, From a Crooked Rib" (716). So convincing was Farah's debut novel in its repre- 
sentation of female subjectivity, that often the author received letters addressed to "Dear Ms Farah". As keynote speaker at an Ibsen conference in 2012 in Norway, Farah outlined the debt owed to Ibsen (and an unnamed female Indian student) in the composition of From a Crooked Rib. Farah recollects how he stood bewildered amidst the literary treasures of the Panjab University library. Drawn by the "sweet smile" of a female student, who notices his confusion, Farah entered into an exchange with her that led to her recommendation that he read Ibsen's A Doll's House: "It's a helluva play, fantastic, and you'll enjoy it" (15). Farah describes the intensity of his engagement with Ibsen's play of European female assertion of independence, which shed light on the character of Ebla, his protagonist, and charted her path to liberation in a remarkably different context:

Flushed with euphoria, fired up, I gave in furiously to an overpowering fever of writing, which flowed with ease. My daylight hours ran into my nights without pause, my notebooks filled with my hurried scrawls. [...] I decided to use [Ibsen's] play as a template for my novel, beginning mine where he ended his. [...] As an aspiring young first time author ready to strike on his own, A Doll's House had a great deal of resonance for me; it provided me with wings with which my imagination could fly at the same time that it supplied me with a kind of rootedness, a rootedness which allowed my plants to germinate and grow my own garden in my own soil. The long and short of it is that I could not have written From a Crooked Rib if I had not read A Doll's House. (16-7)

The title of Farah's keynote address is "Ibsen, In Other Words" which neatly sums up the relationship of From a Crooked Rib with A Doll's House. From a Crooked Rib is A Doll's House "in other words"and in another world. In the context of an African literature field that was dominated by men writing about "bigger" political issues of decolonization and neocolonialism, From a Crooked Rib caused as much of a stir among African feminist academics as Tsitsi Dangarembga's Nervous Conditions did when it was published almost two decades later. (In the interview conducted with the author for the theme issue, Farah voices disappointment in his experience with Heinemann, the first publisher of From a Crooked Rib, and its initial poor marketing of the novel. He also suggests that had his novel featured a young male character, it would have had the major initial impact of other African first novels. However, although From a Crooked Rib was not a novel that put African literature on the world map, it did distinguish Farah within the literary map of Africa, which up to that point had largely reflected a male ethos.) Farah's entry into international literary circuits was aesthetically and politically bold and innovative, features that have persisted in his novels throughout his career. In the first quarter of the twenty-first century, Farah scholarship follows his lead into transformed literary, social and political geographies, as the overview of the articles in this issue in the essay by Reed Way Dasenbrock makes clear.

"Literary provocations: Nuruddin Farah five decades on" would not have been published without the perseverance and patience of the authors. Thank you for submitting articles which were a pleasure to read, and for bearing with me through all the house style rules that I grappled with piecemeal. Thank you also to Hein Willemse for recognizing the need for an intervention into Farah scholarship, and to Jacomien van Niekerk, editor of Tydskrif vir Letterkunde, who, like the poet Virgil, alluded to in many of Farah's novels, held my hand in the descent through the circles of the online submission system and the finer points of the guide for guest editors. From the seventh circle, I would not have come out on the other side without the help of Elham Hosseini, Elaine Ridge and Lisa Julie. Heartfelt appreciation is also due to the reviewers whose recommendations elucidated the key insights of articles. Thank you to you all: Tina Steiner, Aghogho Akpome, Rebecca Fasselt, Betty Govinden, Reed Way Dasenbrock, Harry Sewlall, Harry Garuba, Tommaso Milani, Bhakti Shringarpure, David Jalajel, Geetha Ganga, Shaheed Tayob, Lorenzo Mari, John Masterson, and Simone Brioni. To Alessandro Vescovi, my "Italian Connection"', appreciation for the introduction to Professor Itala Vivan, doyen of Farah studies in Italy, whose ill health prevented her from contributing some reflections on her engagements with Farah's work. Professor Vivan, an Emerita of the University of Milan, has guided more than a generation of postcolonial and African scholars. Her interest in the work of Farah has been a sustained one over decades. Warmest appreciation also is due to Claude Lortie, whose cover photograph of Farah captures something of the spirit of the artist. Thank you to Christopher Forheringham for translating Ubah Cristina Ali Farah's reflective essay. Finally thanks are due to the A. W. Mellon funded project, "Rethinking South African Literature(s)", housed in the Centre for Multilingualism and Diversities Research at the University of the Western Cape, for generously supporting the copyediting of the articles.

This theme issue is dedicated to Professor Harry Garuba, my PhD supervisor, my intellectual mentor, and my friend. Harry passed away on 28 February 2020, just a short period before the publication of this theme issue, to which he contributed in hugely significant ways. To list Harry's creative and scholarly accomplishments would 
require many pages. Suffice it to say that he was a giant in recognizing and promoting the importance of African literature in world literature and culture - a giant on whose shoulders this dwarf was most privileged to be carried.

\section{Works Cited}

Ahmed, Ali Jimale. "The Arab Factor in Somali Culture: The Rise of the Novel in Somalia and Djibouti." Journal of Somali Studies vol. 1, no. 2, 2014, pp. 9-38.

Brown, Duncan. "Reimagining South African Literature?" Journal of Southern African Studies vol. 40, no. 5, 2014, pp. 1109 -23. DOI: https://doi.org/10.1080/03057070.2014.946223.

Farah, Nuruddin. "Ibsen, In Other Words." Nordlit 34, 2015, pp. 15-21.

Ngũgĩ wa Thiong'o. "Nuruddin Farah: A Statement of Nomination to the 1998 Neustadt Jury." World Literature Today vol. 72, no. 4,1998, p. 716

Odeh, Tayseer Abu. "The Pleasures and Pitfalls of Exile and Counterpoint in Farah's Maps." Arab Studies Quarterly vol. 40, no. 2, 2018, pp. 134-54. DOI: https://doi.org/10.13169/arabstudquar.40.2.0134.

Willemse, Hein \& F. Fiona Moolla. Email correspondence. 7 Aug. 2019. 